\title{
Review on in vitro antioxidant activities of Curcuma species commonly used as herbal components in Indonesia
}

\author{
${ }^{1,2,{ }^{*}}$ Rohman, A., ${ }^{3}$ Widodo, H., ${ }^{1}$ Lukitaningsih, E., ${ }^{4}$ Rafi, M., ${ }^{5}$ Nurrulhidayah, A.F. and \\ ${ }^{6}$ Windarsih, A. \\ ${ }^{1}$ Department of Pharmaceutical Chemistry, Faculty of Pharmacy, Universitas Gadjah Mada, Yogyakarta \\ ${ }^{2}$ Institute of Halal Industry and Systems, Universitas Gadjah Mada, Yogyakarta 55281 Indonesia \\ ${ }^{3}$ Study Program of Biotechnology, Gadjah Mada University, Yogyakarta 55281 Indonesia \\ ${ }^{4}$ Department of Chemistry, Faculty of Mathematics and Natural Sciences, IPB University, Jalan Tanjung \\ Kampus IPB Dramaga, Bogor 16680, Indonesia. \\ ${ }^{5}$ International Institute for Halal Research and Training (INHART), International Islamic University \\ Malaysia, Gombak, 50728, Kuala Lumpur, Malaysia \\ ${ }^{6}$ Research Unit for Natural Products Technology (BPTBA), Indonesian Institute of Sciences (LIPI), \\ Yogyakarta, Indonesia
}

\begin{abstract}
Article history:
Received: 15 April 2018 Received in revised form: 13 June 2019

Accepted: 16 June 2019 Available Online: 25 June 2019

\section{Keywords:}

Curcuma longa,

Curcuma xanthorriza,

Antioxidant in vitro,

Curcuminoids
\end{abstract}

\section{DOI:}

https://doi.org/10.26656/fr.2017.4(2).163

\begin{abstract}
Free radicals, reactive nitrogen species (RNS) and reactive oxygen species (ROS) have been known to contribute several degenerative diseases such as cardiovascular diseases, aging, certain types of cancers, rheumatoid arthritis, neurodegenerative, and diabetes mellitus. In order to overcome the negative effects of these radicals, some scientists have explored some natural antioxidants from plants and it's by-products. The antioxidant can be defined as any substances or samples capable of inhibiting free radical reactions in the oxidation reaction. Due to curcuminoids contained, Curcuma species such as Curcuma longa, Curcuma heyneana, Curcuma mangga, and Curcuma xanthorriza were commonly used for herbal components in some traditional medicine. Several in vitro tests been introduced and used to measure antioxidant activities, namely radical scavenging assay using 2,2'-diphenyl-1-picrylhydrazyl (DPPH) and 2,2'-azinobis-(3-ethylbenzothiazoline-6 -sulfonic acid) $\left(\mathrm{ABTS}^{\circ+}\right)$, ferric reducing antioxidant power (FRAP), ferric-thiocyanate, phosphomolybdenum method, cupric ion reducing antioxidant capacity, metal chelating power, beta-carotene bleaching linoleic-ferric-thiocyanate, and thiobarbituric acid methods. This review highlighted the antioxidant activities in vitro of $C$. longa, $C$. heyneana, C. mangga, and C. xanthorriza through several tests. To perform this review, several repute databases were analyzed and used. From this review, it can be stated that Curcuma species have powerful antioxidant activities, therefore they could be potential sources of natural antioxidants and can be used as food supplements.
\end{abstract}

\section{Introduction}

Oxidative stress has been defined as the imbalance between the occurrence of reactive oxygen species (ROS) and reactive nitrogen species (RNS) and the endogenous antioxidants present in human body (Persson et al., 2014). When ROS/RNS interacts with various components in the human body, it forms free radicals or compounds capable of producing free radicals. Because free radicals have an unpaired electron, they are highly reactive and unstable. Free radical can react with some biological components (lipids, proteins, and DNA) which resulted in the formation of a new free radical (Lichtenberg and Pinchuk, 2015). The disadvantage effects of oxidative stress in the human body have become a serious issue. Under oxidative stress condition, the human bodies produce more ROS/RNS such as hydroxyl radicals, nitric oxide radicals, hydrogen peroxide and superoxide anion radicals than endogenous antioxidants either enzymatic antioxidants (e.g.,catalase, superoxide dismutase, glutathione peroxidase (GPx), and non-enzymatic ones (e.g., vitamin C, vitamin E, carotenoids, glutathione, and flavonoids) (Pisoschi and Pop, 2015). The imbalance between ROS/RNS and antioxidants leads to the cell damage (Lefer and Granger, 2000; Bhatia et al., 2003; Uttara et al., 2009) and health associated problems (Uchida, 2000; Steer et al., 2002). 
Some degenerative disease is also associated with this imbalance (Rajendran et al., 2014), including cardiovascular diseases (Gerber et al., 2002), several types of cancers (Pool-Zobel et al., 2005; Kaefer and Milner, 2008), degenerative rheumatoid arthritis (Hadjigogos, 2003), neurodegenerative and Alzheimer's diseases (Di Matteo and Esposito, 2003), aging and diabetes mellitus (Avignon et al., 2012). One solution to solve these problems is the use of diet rich in antioxidant compounds contained in plant sources (Krishnaiah et al., 1996). There are some definitions regarding antioxidant. One of the most commonly used and accepted by scientists is that antioxidants are any substances or any compounds capable of delaying or preventing the oxidation of substrate significantly when present at low levels compared with those of an oxidizable substrate. The oxidizable substrate refers to everything found in the living cells which include lipids, DNA, proteins, and carbohydrates (Al-Jaber et al., 2011). In addition, biological antioxidants are defined as any compounds capable of protecting biological systems against the harmful effects of processes or reaction that can cause excessive oxidation. In our body, some endogenous antioxidants namely any substances having the ability to terminate the formation free radicals or to limit the damage effects caused by the oxidative reaction, are found (Halliwell, 1999).

The substances or compounds can be considered as antioxidants due to its activities as: (1) species scavenger which initiate peroxidation or free radical reactions, (ii) chelators of heavy metal ions so that the metals are unable to generate the reactive species, (iii) quencher of singlet oxygen, (iv) the breaker of free radicals chain reaction, and/or (v) reducing agents. Antioxidants include different classes of compounds, namely carotenoids such as carotenes and xanthophylls, vitamins like ascorbic acid (vitamin C) and tocopherols (vitamin E), and polyphenols such as phenolic acids, flavonoids, lignans and stilbenes (Oroian and Escriche, 2015). Endogenous antioxidants, a product from the body's metabolism, can be either enzymatic or non-enzymatic. Some enzymatic antioxidants include superoxide dismutase (SOD), catalase (CAT), glutathione peroxidase (GPx), glutathione reductase (GR), and peroxiredoxins (Prxs). The nonenzymatic antioxidants are represented by Ferritin, Transferrin, Myoglobin, Lactoferrin Metallothioneins, Coenzyme Q10 Ceruloplasmin, Glutathione and Polyamines (Babula et al., 2012). Antioxidants can also be classified as synthetic antioxidants like Butylated hydroxyanisole (BHA), Butylated hydroxytoluene (BHT), tertButylhydroquinone (TBHQ), propyl gallate and natural antioxidants derived from plants (Shahidi and Zhong, 2010). Due to the safety concerns for synthetic antioxidants, the natural antioxidants derived from plants are chosen to be used as a food supplement which functions as functional foods (Embuscado, 2018). Curcuma species which include turmeric (Curcuma longa), java turmeric (Curcuma xanthorriza), Temu mangga (Curcuma mangga) and Curcuma heneynea. The aim of this review was to highlight the antioxidant activities in vitro of $C$. longa, C. heyneana, C. mangga and $C$. xanthorriza through several tests of antiradical assay, ferric reducing antioxidant power, ferricthiocyanate, phosphomolybdenum method, cupric ion reducing antioxidant capacity, metal chelating power, beta-carotene bleaching linoleic-ferric-thiocyanate, and thiobarbituric acid methods.

\section{Materials and methods}

During performing this review, the abstracts, reports, and research papers related to antioxidant activities of Curcuma species are identified, downloaded from several databases including Scopus, PubMed, and Google Scholar. The keywords used during searching for information was (antioxidant + Curcuma + in vitro) in the month of January-March 2019.

\subsection{Evaluation of antioxidant activities in vitro}

Several tests have been used for the evaluation of antioxidant activities in vitro (Moniruzzaman et al., 2012), namely (1) radical scavenging methods using several radicals namely 2,2'-diphenyl-1-picrylhydrazyl (DPPH), 2,2'-azinobis-(3-ethylbenzothiazoline-6sulfonic acid) $\left(\mathrm{ABTS}^{\cdot+}\right)$, hydrogen, nitric oxide, and peroxynitrite radicals, (2) reducing power including ferric reducing antioxidant power (FRAP), ferricthiocyanate, phosphomolybdenum method, cupric ion reducing antioxidant capacity (3) metal chelating power, (4) lipid peroxide inhibition using beta-carotene bleaching linoleic-ferric-thiocyanate, and thiobarbituric acid (TBA) methods (Nur Alam et al., 2013; Schaich and Xie, 2015). Among antioxidant assays, radical scavenging methods are the most commonly used for antioxidant screening of plant extracts (Permatasari and Rohman, 2016). The parameter of $\mathrm{IC}_{50}$ (concentration of sample solution capable of scavenging $50 \%$ DPPH radicals) is used to assess the power of antiradical. The lower the $\mathrm{IC}_{50}$ value, the higher the antiradical (Rohman et al., 2006; Sharma and Bhat, 2016).

The reducing power was based on the capability of plant samples to reduce the oxidation systems. For example, ferric reducing activity power (FRAP) is relied on the capability of antioxidant to reduce the complex of Fe (III)-TPTZ or 2,4,6-tripyridyl-s-triazine to produce the intensely colored Fe (II)-TPTZ, having maximum absorption at $593 \mathrm{~nm}$. The antioxidant capacity using 
FRAP method can be evaluated by comparing the absorption change in the test mixture with that obtained from increasing concentrations of $\mathrm{Fe}^{3+}$ and expressed as $\mathrm{mM}$ of $\mathrm{Fe}^{2+}$ equivalents per $\mathrm{kg}$ or per $\mathrm{L}$ sample (Nur Alam et al., 2013). In the phosphomolybdenum method, the antioxidant activity was measured based on the reduction of Mo (VI) to Mo (V) by the samples and subsequently the complex formation of a green phosphate-Mo (V) at acidic pH (Prieto et al., 1999).

Metal chelating power was also considered as an antioxidant, because the excess of ree metals has implicated in the induction and formation of free radicals in the biological systems (Wong et al., 2014). This assay was based on the measurement of iron-ferrozine complex. Ferro ion $\left(\mathrm{Fe}^{2+}\right)$, as representative of metal, can form a complex with chelates of ferrozine to obtain red colour having maximum absorption at $562 \mathrm{~nm}$. This reaction is limited in the presence of other chelating agents and results in a decrease of the red color of ferrozine- $\mathrm{Fe}^{2+}$ complexes. Measurement of the color reduction due to the addition of evaluated samples for inhibition of complexation reaction $\mathrm{Fe}^{2+}$-ferrozine determines the chelating activity. Ethylene diamine tetra acetate (EDTA) or citric acid can be used as a positive control (Soler-Rivas et al., 2000).

Lipid peroxidation inhibition was based on the inhibition of peroxide formed during initiation step of free radical reaction. This assay can be represented by $\beta$ carotene bleaching and linoleic-ferric-thiocyanate (FTC) methods. $\beta$-carotene bleaching (BCB) method is rapid method used for antioxidants screening, mainly relied on the principle that an unsaturated fatty acid as represented by linoleic acid (C18:2) was oxidized by reactive oxygen Species, produced by oxygenated water. The oxidized products formed radicals which then oxidized $\beta$-carotene to yield discoloration of beta-carotene. The antioxidant components decrease the extent of discoloration, as measured at $434 \mathrm{~nm}$ (Kabouche et al., 2007). In FTC method, the level of peroxide at the initiation stage of lipid peroxidation was determined. The peroxides are formed during linoleic acid oxidation. The peroxides oxidize $\mathrm{Fe}^{2+}$ to $\mathrm{Fe}^{3+}$. The $\mathrm{Fe}^{3+}$ ions formed are complexed with thiocyanate to form red color of $\mathrm{Fe}$ $\left(\mathrm{CNS}_{6}\right)^{3-}$, with maximum absorbance at $500 \mathrm{~nm}$. The lower absorbance value indicated the higher the antioxidant activity (Saraswathy et al., 2008). While, TBA method was based on the reaction between malonaldehyde, representative of secondary oxidation products, with barbituric acid to form red-colored complex with maximum absorbance at $532 \mathrm{~nm}$ (Ghani et al., 2017).

\subsection{Antioxidant activity of Curcuma longa}

Curcuma longa, belonging of family Zingiberaceae, is probably a native plant from Southeast Asia. It is cultivated mostly in India followed by Bangladesh, China, Thailand, Cambodia, Indonesia, Malaysia, and Philippines (Ravindran et al., 2007). In Indonesia, $C$. longa is recognized as kunyit. The dried rhizomes of $C$. longa are also known as turmeric. C. longa has been used as a medicinal plant for centuries. It is a famous medicinal plant and is believed to have many biological activities (Awin et al., 2016).

The rhizomes of $C$. longa have orange-brown, pale yellow, or red yellow in color and it is usually harvested 7-9 months after planting. The powder of $C$. longa rhizomes or ground turmeric is prepared from dried finger rhizomes and it has yellow or red-yellow powder in color (Li et al., 2011). Figure 1 shows the rhizomes and powdered rhizomes of $C$. longa, $C$. heyneana, $C$. mangga and $C$. xanthorriza. Turmeric has been widely used as a spice, food, preservative, coloring agent, and cosmetics in most of the South Asian countries. Recently, C. longa is extensively used in the treatment of various diseases because of its pharmacological activities. Several publications have reported that $C$. longa has numerous biological activities related to antioxidant, anti-inflammatory, and cancer preventive properties (Dall'Acqua et al., 2016). Nowadays, research on C. longa is focused on antioxidant, anti-inflammatory, hepatoprotective, antimicrobial, and anticarcinogenic properties (Ravindran et al., 2007).

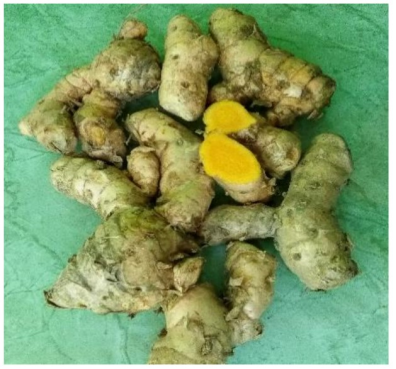

Curcuma xanthorrhiza

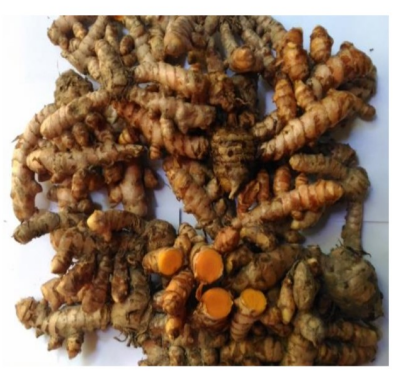

Curcuma longa

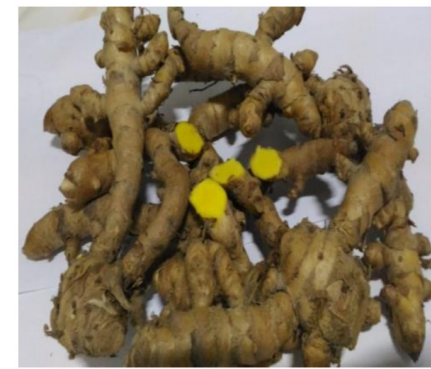

Curcuma heyneana

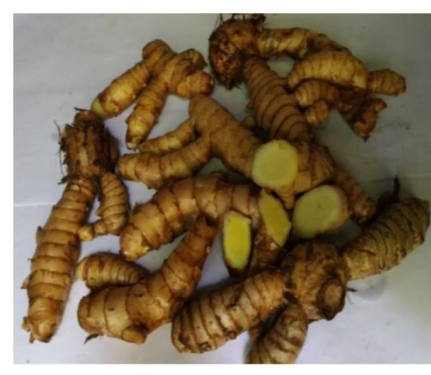

Curcuma mangga
Figure 1. The rhizomes of Curcuma species.

Members of Curcuma especially C. longa has the rich contents in curcuminoids that consist of curcumin, demethoxycurcumin, and bisdemethoxycurcumin (Jung 
et al., 2012). Figure 2 shows the structure of curcuminoids. The rhizomes of $C$. longa contain the greatest amount of pigments and has been prized for its coloring, flavoring, and digestive properties. Curcumin is a yellow pigment, possesses many pharmacological activities. The active constituents of turmeric are the curcumin (diferuloylmethane) and several volatile oils such as turmerone, atlantone, and zingiberone.

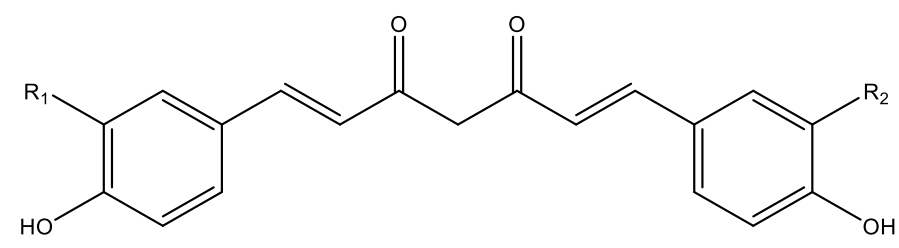

Figure 2. Chemical structure of curcuminoids (Curcumin, $\mathrm{R} 1=\mathrm{R} 2=\mathrm{OCH} 3$; demethoxycurcumin, $\mathrm{R} 1=\mathrm{OCH} 3, \quad \mathrm{R} 2=\mathrm{H}$; bisdemethoxycurcumin, R1=R2=H) (Rohman, 2012).

C. longa rhizome also contains sugars, protein, and resin (Li et al., 2011). In a standard form, turmeric contains moisture $(>9 \%)$, curcumin $(5-6.6 \%)$, mould $(<3 \%)$, and volatile oils $(<3.5 \%)$. The other compounds of turmeric contents are a variety of sesquiterpenes, like germacrone, termerone, alfa curcumene, zingiberene, and curcumenone. Tanvir et al. (2017) have investigated antioxidant activity in vitro of $C$. longa from varieties of Kopil moni mura, Kopil moni chora, Chittagong mura, and Chittagong chora in Bangladesh via analysis of DPPH radical scavenging assay and ferric reducing antioxidant power. Among these varieties, the ethanolic extract of C. longa variety of Khulna's mura exhibited the highest DPPH radical-scavenging activity with the lowest $\mathrm{IC}_{50}$ value of $1.08 \mu \mathrm{g} / \mathrm{mL}$, while a variety of Khulna's chora showed the highest FRAP value of $4204.46 \pm 74.48 \mu \mathrm{M} \mathrm{Fe}(\mathrm{II}) / 100 \mathrm{~g}$ sample. The different fractions of methanolic extract of $C$. longa have been investigated as antioxidant in vitro. The fraction of ethylacetate (EtOAc) showed the highest DPPH $\mathrm{IC}_{50}$ of $9.86 \mathrm{mg} / \mathrm{mL}$. EtOAC fraction also revealed the highest ABTS radical scavenging and FRAP values. These activities were concentration dependent and highly correlated with phenolic contents present in that fraction (Choi, 2009). Nahak and Sahu (2011) have compared DPPH antiradical assay of ethanolic extract of C. longa and $C$. aromatica. The research showed that among extracts and fractions evaluated, the ethanolic fraction of C. longa revealed highest free radical scavenging activity accounting of $74.61 \pm 0.02 \%$ due to the presence of high amount of curcumin, while the ethanolic extracts and fractions of $C$. aromatica exhibited poor to moderate antioxidants. Unlike vitamin $\mathrm{E}$ and vitamin $\mathrm{C}$, the antioxidant properties were not degraded by food processing such as cooking provides benefits (Krup et al., 2013). It is also reported that water-soluble and fatsoluble extracts of $C$. longa and its curcumin component revealed strong antioxidant activity, comparable to vitamin C (Labban, 2014).

\subsection{Antioxidant activity of Curcuma heyneana in vitro}

Curcuma heyneana is widespread in tropical country. In Indonesia, especially in Java, C. heyneana (Figure 3) is also known as Temu giring. The main important part of this plant which has pharmacological properties is the rhizome. C. heyneana rhizome is yellow in color (Widyaningsih, 2013). Rhizomes of C. heyneana have some pharmacological properties. The saponin and flavonoid in these rhizomes provide a potent antioxidant and anti-inflammatory. The volatile oil has the ability to kill Fasciola hepatica worms (Woelansari et al., 2013). Widyaningsih (2013) reported that ethanolic extract of C. heyneana rhizomes could decrease triglyceride level. $C$. heyneana rhizomes have chemical components such as volatile oil $0.8-3 \%$, amylum, lipids, saponin, yellow pigment, and flavonoid. The rhizomes contain curcumin that gives a yellow color, essential oils, starch, resins, fats, tannins, saponins, and flavonoids.

Zulaikha (2017) has investigated the antioxidant activities of chloroform extract of $C$. heyneana and the result showed that $C$. heyneana extract had strong antioxidant activities using DPPH radical scavenging assay with $\mathrm{IC}_{50}$ of $50.93 \mu \mathrm{g} / \mathrm{mL}$, ABTS DPPH radical scavenging assay with $\mathrm{IC}_{50}$ of $90.90 \mu \mathrm{g} / \mathrm{mL}$ and FRAP value of $85.70 \mathrm{mM}$.

\subsection{Antioxidant activity of Curcuma mangga}

Curcuma mangga is distributed widely from Asia to Africa and Australia (Sasikumar, 2005). It is closely related to turmeric. C. mangga has the characteristics of raw mango aroma. Therefore in some countries, it is more recognized as mango ginger. C. mangga is also often called as Curcuma amada. The rhizomes are fleshy, buff coloured, $5-10 \mathrm{~cm}$ long, $2-5 \mathrm{~cm}$ in diameter and demarcated into nodes and internodes (Sheeja and Nair, 2012). The major chemical components include starch, phenolic acids, volatile oils, curcuminoids and terpenoids. These rhizomes are rich in phenolic contents including caffeic acid and ferulic acid. The terpenoids content are difurocumenonol, amadannulen and amadaldehyde.

Jalip et al. (2013) have compared DPPH radical scavenging activities of methanolic extracts of $C$. heyneana, C. mangga, C. aeruginosa, C. phaeocaulis and C. purpurascens. Among these, C. purpurascens has the highest antiradical activities with $\mathrm{IC}_{50}$ of $36.30 \mu \mathrm{g} /$ $\mathrm{mL}$ followed by $C$. mangga, $C$. phaeocaulis, $C$. heyneana, and C. aeruginosa with $\mathrm{IC}_{50}$ values of 90.42 , 110.92, 155.68 and $199.71 \mu \mathrm{g} / \mathrm{mL}$, respectively. The $\mathrm{H}_{2} \mathrm{O}_{2}$-scavenging activity of fractions of $C$. mangga has 
been evaluated by Pujimulyani et al. (2018). Ethyl acetate fraction revealed the highest in $\mathrm{H}_{2} \mathrm{O}_{2}$-scavenging activity with $\mathrm{IC}_{50}$ of $162.78 \mu \mathrm{g} / \mathrm{mL}$, compared to positive control of butylated hydroxytoluene (BHT) with $\mathrm{IC}_{50}$ of $179.86 \mu \mathrm{g} / \mathrm{mL}$. Indis and Kurniawan (2016) have reported that water extract of $C$. mangga has $\mathrm{IC}_{50}$ value of $212.70 \mu \mathrm{g} / \mathrm{mL}$. The bleaching treatment of C. mangga increased the antioxidant activity and quercetin content via hydrolyzing quercetin-3-rutinoside into quercetin (Pujimulyani et al., 2012).

\subsection{Antioxidant activities of Curcuma xanthorriza}

Curcuma xanthorrhiza rhizome (Family of Zingiberaceae, Figure 1), also known as Javanese turmeric or temulawak, is a widely used traditional plant medicine from Indonesia (Ramdani et al., 2016). The main substances of $C$. xanthorrhiza are starch (48.18$59.64 \%)$, volatile oils (3-12\%) such as phelandren, camphor, tumerol, sineol, borneol, and xanthorrhizol $(1.48-1.63 \%)$, sesquiterpenes ( $\beta$-curcumene, arcurcumene, bisabolane, lactone germacone), flavonoids (catechin, epicatechin, quercetin, myricetin, kaemferol, apigenin, luteolin, naringenin), and also curcuminoids.

Qader et al. (2011) have compared antioxidant activities in vitro of ethanolic and aqueous extracts of $C$. xanthorriza using DPPH radical scavenging and FRAP methods along with total phenolics compounds (TPC). At a concentration of $1 \mathrm{mg} / \mathrm{mL}$, the ethanolic extract had the higher DPPH radical scavenging percentage (64.0\%) than aqueous extract (62.3\%) and revealed higher FRAP value of $2955 \mathrm{mmol} / \mathrm{g}$ compared to aqueous extract accounting of $358 \mathrm{mmol} / \mathrm{g}$. These FRAP values correlated with TPC present in both extracts, in which ethanolic extract had higher TPC $(88.0 \mathrm{mg} / \mathrm{g})$ over aqueous extract $(24.3 \mathrm{mg} / \mathrm{g})$. The similar results were also obtained in which ethanolic extract of C. longa revealed higher antioxidant activities over aqueous extract using DPPH and ABTS radical scavenging assays, FRAP, and lipid peroxidation inhibition (Tilak et al., 2004).

\section{Conclusion}

Curcuma species namely Curcuma longa, $C$. xanthorriza, C. mangga and $C$. heyneana which contained some phenolics compounds, mainly curcuminoids, exhibited antioxidant activities in vitro through several mechanisms namely radical scavenging, reducing power and lipid peroxidation. Curcuma species is also herbal components in several traditional medicine preparations. In addition, Curcuma species is widely used as a preventive agent to any diseases caused by excessive radicals.

\section{Acknowledgement}

The authors acknowledged the Ministry of Research and Higher Education, Republic of Indonesia for financial support during preparing this review article through scheme World Class Research 2019 with contract number of 1973/UN1.DITLIT/DIT-LIT/ $\mathrm{LT} / 2019$.

\section{References}

Al-Jaber, N.A., Awaad, A.S. and Moses, J.E. (2011). Review on some antioxidant plants growing in Arab world. Journal of Saudi Chemical Society, 15(4), 293-307. https://doi.org/10.1016/j.jscs.2011.07.004

Avignon, A., Hokayem, M., Bisbal, C. and Lambert, K. (2012). Dietary antioxidants: do they have a role to play in the ongoing fight against abnormal glucose metabolism? Nutrition, 28(7-8), 715-721. https:// doi.org/10.1016/j.nut.2012.01.001

Awin, T., Mediani, A., Shaari, K., Faudzi, S.M.M., Sukari, M.A.H., Lajis N.H. and Abas, F. (2016). Phytochemical profiles and biological activities of Curcuma species subjected to different drying methods and solvent systems: NMR-based metabolomics approach. Industrial Crops Production, 94, 342-352. https://doi.org/10.1016/ j.indcrop.2016.08.020

Babula, P., Masarik, M., Adam, V., Eckschlager, T., Stiborova, M., Trnkova, L., Skutkova, H., Provaznik, I. Hubalek, J. and Kizek, R. (2012). Mammalian metallothioneins: properties and functions. Metallomics, 4(8), 739-750. https://doi.org/10.1039/ c2mt20081c

Bhatia, S., Shukla, R., Madhu, S.V., Gambhir, J.K. and Prabhu, K.M. (2003). Antioxidant status, lipid peroxidation and $\mathrm{NO}$ end products in patients of type 2 diabetes mellitus with nephropathy. Clinical Biochemistry, 36(7), 557-562. https:// doi.org/10.1016/S0009-9120(03)00094-8.

Choi, H.Y. (2009). Antioxidant Activity of Curcuma Longa L., Novel Foodstuff. Molecular Cell Toxicology, 5(3), 237-242.

Dall'Acqua, S., Stocchero, M., Boschiero, I., Schiavon, M., Golob, S., Uddin, J., Voinovich, D., Mammi, S. and Schievano, E. (2016). New findings on the in vivo antioxidant activity of Curcuma longa extract by an integrated 1H-NMR and HPLC-MS metabolomic approach. Fitoterapia, 109, 125-31. https://doi.org/10.1016/j.fitote.2015.12.013

Di Matteo, V. and Esposito, E. (2003). Biochemical and therapeutic effects of antioxidants in the treatment of Alzheimer's disease, Parkinson's disease, and amyotrophic lateral sclerosis. Current Drug Targets 
- CNS and Neurology Disorders, 2(2), 95-107. https://doi.org/10.2174/1568007033482959

Embuscado, M.E. (2018). Spices and herbs: Natural sources of antioxidants - a mini review. Journal of Functional Foods, 18(Part B), 811-819. https:// doi.org/10.1016/j.jff.2015.03.005

Gerber, M., Boutron-Ruault, M.C., Hercberg, S., Riboli, E., Scalbert, A. and Siess, M.H. (2002). Food and Cancer: state of the art about the protective effect of fruits and vegetables. Bulletin Cancer, 89(3), 293312.

Ghani Md.A., Barril C., Bedgood Jr. D.R., and Prenzler, P.D. (2017). Review Measurement of antioxidant activity with the thiobarbituric acid reactive substances assay. Food Chemistry, 230, 195-207. https://doi.org/10.1016/j.foodchem.2017.02.127

Hadjigogos, K. (2003). The role of free radicals in the pathogenesis of rheumatoid arthritis. Panminerva Medicine, 45(1), 7-13.

Halliwell, B. (1999). Establishing the significance and optimal intake of dietary antioxidants: the biomarker concept. Nutrition Reviews, 57(4), 104-113. https:// doi.org/10.1111/j.1753-4887.1999.tb06933.x

Indis, N.A. and Kurniawan, F. (2016). Determination of free radical scavenging activity from aqueous extract of Curcuma mangga by DPPH method. Journal of Physics: Conference Series 710, 012043. https:// doi.org/10.1088/1742-6596/710/1/012043

Jalip, I.S., Suprihatin, Wiryanti, I. and Sinaga, E. (2013). Antioxidant activity and total flavonoids content of Curcuma rhizome extract. International Conference on the $4^{\text {th }}$ Green Technology. Malang, Indonesia: Faculty of Science and Technology Islamic of University State Maulana Malik Ibrahim.

Jung, Y., Lee, J., Kim, H.K., Moon, B.C., Ji, Y., Ryu, D.H. and Hwang, G-S. (2012). Metabolite profiling of Curcuma species grown in different regions using 1H-NMR spectroscopy and multivariate analysis. Analyst, 137(23), 5597-5606. https:// doi.org/10.1039/c2an35397k

Kabouche, A., Kabouche, Z., Ozturk M., Kolal, U. and Topc, u, G. (2007). Antioxidant abietane diterpenoids from Salvia barrelieri. Food Chemistry, 102(4), 1281 -1287. Doi: https://doi.org/10.1016/ j.foodchem.2006.07.021

Kaefer, C.M. and Milner, J.A. (2008). The role of herbs and spices in cancer prevention. The Journal of Nutrition Biochemistry, 19(6), 347-361. https:// doi.org/10.1016/j.jnutbio.2007.11.003

Krishnaiah, D., Sarbatly, R. and Nithyanandam, R. (2011). A review of the antioxidant potential of medicinal plant species. Food and Bioproducts
Processing, 89(3), 217-233. https://doi.org/10.1016/ j.fbp.2010.04.008

Krup, V., Prakash, L.H. and Harini, A. (2013). Pharmacological Activities of Turmeric (Curcuma longa Linn): A Review. Journal of Homeopathy and Ayurvedic Medicine, 2, 133-137. https:// doi.org/10.4172/2167-1206.1000133

Labban, L. (2014). Medicinal and pharmacological properties of Turmeric (Curcuma longa): A review. International Journal of Pharmaceutical and Biomedical Science, 5(1), 17-23.

Lefer, D.J. and Granger, D.N. (2000). Oxidative stress and cardiac disease. American Journal of Medicine, 109(4), 315-323. https://doi.org/10.1016/S00029343(00)00467-8

Li, S., Yuan W., Deng, G., Wang, P., Yang, P. and Aggarwal, B. (2011). Chemical composition and product quality control of turmeric Curcuma longa L. Pharmaceutical Crops, 2, 28-54. https:// doi.org/10.2174/2210290601102010028

Lichtenberg, D. and Pinchuk, I. (2015). Mini review Oxidative stress, the term and the concept. Biochemical and Biophysical Research Communications, 461(3), 441-444. Doi: https:// doi.org/10.1016/j.bbrc.2015.04.062

Moniruzzaman, M., Khalil, M.I., Sulaiman, S.A. and Gan, S.H. (2012). Advances in the Analytical Methods for Determining the Antioxidant Properties of Honey: A Review. African Journal of Traditional, Complementary, and Alternative Medicines, 9(1), 36 -42. Doi: https://doi.org/10.4314/ajtcam.v9i1.5

Nahak, G. and Sahu, R.K. (2011). Evaluation in comparative antioxidant activity of Curcuma longa and Curcuma aromatica. Natural Products: An Indian Journal, 7(2), 57-60.

Nur Alam, M., Bristi, N.J. and Rafiquzzam, M. (2013). Review on in vivo and in vitro methods evaluation of antioxidant activity. Saudi Pharmaceutical Journal, 21(2), 143-152. https://doi.org/10.1016/ j.jsps.2012.05.002

Oroian, M. and Escriche, I. (2015). Review Antioxidants: Characterization, natural sources, extraction and analysis. Food Research International, 74, 10-36. https://doi.org/10.1016/ j.foodres.2015.04.018

Permatasari, L. and Rohman, A. (2016). 2,2'-diphenyl-1picrylhydrazyl (DPPH) radical scavenging activity of extracts and fractions of Rambutan (Nephelium lappaceum L) peel. Research Journal of Phytochemistry, 10(2), 75-80. https:// doi.org/10.3923/rjphyto.2016.75.80

Persson, T., Popescu, B.O. and Cedazo-Minguez, A. 
(2014). Oxidative stress in Alzheimer's disease: why did antioxidant therapy fail. Oxidative Medicine and Cell Longevity, 2014, 1-11. https:// doi.org/10.1155/2014/427318

Pisoschi, A.M. and Pop, A. (2015). The role of antioxidants in the chemistry of oxidative stress: A review. European Journal of Medicinal Chemistry, 97, 55-74. https://doi.org/10.1016/ j.ejmech.2015.04.040

Pool-Zobel, B., Veeriah, S. and Bohmer, F.D. (2005). Modulation of xenobiotic metabolising enzymes by anticarcinogens - focus on glutathione S-transferases and their role as targets of dietary chemoprevention in colorectal carcinogenesis. Mutation Research and Fundamental Molecular Mechanism, Mutagen, 591 (1-2), 74-92. https://doi.org/10.1016/ j.mrfmmm.2005.04.020

Prieto, P., Pineda, M. and Aguilar, M. (1999). Spectrophotometric Quantitation of Antioxidant Capacity through the Formation of a Phosphomolybdenum Complex: Specific Application to the Determination of Vitamin E. Analytical Biochemistry, 269(2), 337-341. https:// doi.org/10.1006/abio.1999.4019

Pujimulyani, D., Yulianto, W.A., Setyowati, A., Arumwardana, S. and Rizal, R. (2018). Antidiabetic and antioxidant potential of Curcuma mangga Val extract and fractions. Asian Journal of Agriculture and Biology, 6(2),162-168.

Pujimulyani, D., Raharjo, S., Marsono, Y. and Santoso, U. (2012). The effect of blanching on antioxidant activity and glycosides of white saffron (Curcuma mangga Val.). International Food Research Journal, 19(2), 617-621.

Qader, S.W., Abdulla, M.A., Chua, L.S., Najim, N., Mat Zain, M. and Hamdan, S. (2011). Antioxidant, total phenolic content and cytotoxicity evaluation of selected Malaysian plants. Molecules, 16(4), 34333443. https://doi.org/10.3390/molecules 16043433

Rajendran, P., Nandakumar, N., Rengarajan, T., Palaniswami, R., Gnanadhas, E.N., Lakshminarasaiah, U., Gopas, J. and Nishigaki I. (2014). Antioxidants and human diseases. Clinica Chimica Acta, 436, 332-347. https:// doi.org/10.1016/j.cca.2014.06.004

Ramdani, E.D., Marlupi, U.D., Sinambela, J. and Tjandrawinata, R.R. (2016). A New Method of Xanthorrhizol Isolation from the Rhizome Extract of Curcuma xanthorrhiza. Scholars Academic Journal of Bioscience, 4(9), 732-737.

Ravindran, P.N., Nirmal Babu, K. and Sivaraman K. (Eds.). (2007). Turmeric: the genus Curcuma,
Medicinal and aromatic plants--industrial profiles. Boca Raton, Florida, USA: CRC Press

Rohman, A. (2012). Analysis of curcuminoids in food and pharmaceutical products. International Food Research Journal, 19(1), 19 -27.

Rohman, A., Riyanto, S. and Utari, D. (2006). Antioxidant activities, total phenolic and flavonoid contents of ethyl acetate extract of Mengkudu (Morindacitrifolia, L) fruit and its fractions. Indonesia Journal of Pharmacy, 17(3), 136- 142.

Sasikumar, B. (2005). Genetic resources of Curcuma: diversity, characterization and utilization. Plant Genetic Resources, 3(2), 230-251. https:// doi.org/10.1079/PGR200574

Saraswathy, A., Devi, S.N. and Ramasamy, D. (2008). Antioxidant, Heavy Metals and Elemental Analysis of Holoptelea integrifolia Planch. Indian Journal of Pharmaceutical Sciences, 70(5), 683-576. https:// doi.org/10.4103/0250-474X.45419

Schaich, K.M. and Xie, X.T.J. (2015). Reprint of "Hurdles and pitfalls in measuring antioxidant efficacy: A critical evaluation of ABTS, DPPH, and ORAC assays". Journal of Functional Foods, 18 (Part B), 782-796. https://doi.org/10.1016/ j.jff.2015.05.024

Shahidi, F. and Zhong, Y. (2010). Novel antioxidants in food preservation and health promotion. European Journal of Lipid Science and Technology, 112(9), 930-940. https://doi.org/10.1002/ejlt.201000044

Sharma, O.P. and Bhat, T.K. (2009). DPPH antioxidant assay revisited. Food Chemistry, 113(4), 1202-1205. https://doi.org/10.1016/j.foodchem.2008.08.008

Sheeja, A.D.B. and Nair, M.S. (2012). Phytochemical constituents of Curcuma amada. Biochemical Systematics and Ecology, 44, 264-266. https:// doi.org/10.1016/j.bse.2012.06.008

Soler-Rivas, C., Espin, J.C. and Wichers, H.J. (2000). An easy and fast test to compare total free radical scavenger capacity of foodstuffs. Phytochemical Analysis, 11(5), 330-338. https:// doi.org/10.1002/1099-1565(200009/10) 11:5<330::AID-PCA534>3.0.CO;2-G

Steer, P., Milligard, J., Sarabi, D.M., Wessby, B. and Kahan, T. (2002). Cardiac and vascular structure and function are related to lipid peroxidation and metabolism. Lipids, 37(3), 231-236. https:// doi.org/10.1007/s11745-002-0885-3

Tanvir, E.M., Sakib Hossen, M. and Fuad Hossain, M. (2017). Antioxidant Properties of Popular Turmeric (Curcuma longa) Varieties from Bangladesh. Journal of Food Quality, 2017, 1-8. https:// doi.org/10.1155/2017/8471785. 
Tilak, J.C., Banerjee, M., Mohan, H. and Devasagayam, T.P.A. (2004). Antioxidant availability of turmeric in relation to its medicinal and culinary uses. Phytotherapy Research, 18(10), 798-804. https:// doi.org/10.1002/ptr.1553

Uchida, K. (2000). Role of reactive aldehyde in cardiovascular diseases. Free Radical and Biology Medicine, 28(12), 1685-1696. https:// doi.org/10.1016/S0891-5849(00)00226-4

Uttara, B., Singh, A.V., Zamboni, P. and Mahajan R.T. (2009). Oxidative Stress and Neurodegenerative Diseases: A Review of Upstream and Downstream Antioxidant Therapeutic Options. Current Neuropharmacology, 7(1), 65-74. https:// doi.org/10.2174/157015909787602823

Widyaningsih, W. (2013). Efek ekstrak etanol rimpang temugiring Curcuma heyneana val terhadap kadar trigliserida. Pharmaciana, 19(1), 55-65. https:// doi.org/10.12928/pharmaciana.v1i1.516. [In Bahasa Indonesia].

Woelansari, E.D., Puspitasari, A. and Rachmaniyah (2013). Effect of rimpang temu giring Curcuma heyneana Val. and V. Zijp and rimpang temu hitam Curcuma aeruginosa Roxb. boiled water on the mortality of Fasciola hepatica worm in vitro. Folia Medica Indonesiana, 49, 62-65

Wong, F-C., Yong, A-L., Ting, E.P-S., Khoo, S-C., Ong, H-C. and Chai, T-T. (2014). Antioxidant, Metal Chelating, Anti-glucosidase Activities and Phytochemical Analysis of Selected Tropical Medicinal Plants. Iranian Journal of Pharmaceutical Research, 13(4), 1409-1415.

Zulaikha, M.Y.N. (2017). Chemical constituents of Curcuma Heyneana and Curcuma Zedoaria. Malaysia: Universiti Teknologi Malaysia, MSc. Thesis. 